\title{
КРОС-КУЛЬТУРНА КОМПЕТЕНТНІСТЬ У НАВЧАННІ УКРАЇНСЬКОЇ МОВИ ЯК ІНОЗЕМНОЇ
}

Пальчикова О. О. Крос-культурна компетентність у навчанні української мови як іноземної.

У статті розкрита сутність поняття «крос-культурна компетентність», визначено структуру крос-культурної компетентності та проаналізовано етапи іï формування.

Ключові слова: компетентність, компетенція, крос-культурна компетентність, міжкультурні контакти.

Пальчикова А. А. Кросс-культурная компетентность в обучении украинскому языку как иностранному.

В статье раскрыта сущность понятия «кросс-культурная компетентность», определена структура кросс-культурной компетентности и проанализированы этапы ее формирования.

Ключевые слова: компетентность, компетенція, кросс-культурная компетентность, межкультурные контакты. language.

Palchickova O. O. Cross-cultural competency during training Ukrainian as a foreign

The article clarifies a concept "cross-cultural competency", defines the structure of cross-cultural competency and analyses the stages of its formation.

Key words: competency, competence, cross-cultural competency, cross-cultural contacts.

Після вступу у світовий економічний, політичний, науковий та освітній простір Україна зосередила увагу на розширенні культурних меж, побудові стійких i довготривалих стосунків із державамипартнерами, поміж яких є країни Північної та Південної Америки, 
Західної, Центральної і Східної Свропи, Африки й Азії. Отримання статусу самостійної незалежної держави та одночасне поширення глобалізаційних процесів на всі сфери життєдіяльності викликало зацікавленість іноземних країн у створенні успішного політичного, ділового, культурного та освітнього тандему з Україною, необхідною передумовою чого $є$ володіння українською мовою.

Установлення крос-культурних відносин із країнами зарубіжжя вимагає від України певної відповідальності за підготовку іноземних фахівців, а необхідність спілкування, потреба у взаєморозумінні та продуктивній співпраці, у свою чергу, спонукають іноземне студентство до міжкультурної комунікації, що є нездійсненною без оволодіння практичними знаннями, уміннями та навичками спілкування. Отже, стає очевидним, що взаємодія іноземних культур на теренах України значною мірою впливає на освітній процес, породжуючи проблему пошуку ефективних підходів до засвоєння української мови іноземними студентами.

На сучасному етапі навчання іноземці повинні якісно володіти не лише навичками міжкультурної комунікації, а також знаннями про те, у яких саме ситуаціях та за яких умов слід вживати ті чи ті слова, вирази, речення. Не в той час і не в тому місці вжите слово, жарт або прохання може поставити слухача в незручне становище, образити чи принизити його, або ж навпаки - розсмішити співрозмовника і знітити мовця. Наведені вище незручності, що виникають під час спілкування $€$ наслідками мовних бар'єрів, незнання культурного етикету, традицій, звичаїв народу, мова якого вивчається, цінностей, особливостей менталітету загалом. У сукупності окреслені елементи культури формують крос-культурну компетентність, головною особливістю якої є здатність побачити спільне в культурах країн, а також той відрізок, на якому відбувається непорозуміння, «зіткнення» або конфлікт культур, виникають суперечності між їхніми представниками. Одне 3 нерозв'язаних i гострих питань сучасної освіти, що постало перед педагогами ВНЗ - сформувати уміння та навички крос-культурної компетентності студентів-іноземців під час навчання української мови.

Проблема формування крос-культурної компетентності є новою, недостатньо дослідженою цариною, проте надзвичайно актуальною, тому 3 кожним днем привертає все більше уваги з боку педагогів, методистів і дидактів. Такий інтерес до проблеми крос-культурної

() О. О. Пальчикова, 2012. 
взаємодії, а також пошук нових підходів і методів для реалізації кроскультурної освіти пояснюється гуманістичною спрямованістю освітнього процесу, де особистісні якості, культурна обізнаність, суб'єктна взаємодія стають дедалі важливішими, аніж просто знання мови. Так, іноземному студенту досить важко оволодіти мовними і мовленнєвими уміннями і навичками, якщо він погано орієнтується у культурному просторі України. Набагато цікавіше та простіше вивчати мову не ізольовано від соціокультурної реальності, а безпосередньо в самому іiі осередку. Отже, процес оволодіння мовним матеріалом і мовленням значно пришвидшиться, якщо під час занять 3 української мови будуть використані тексти художніх творів, в яких описується життя і побут героїв, яскраво виражений менталітет; країнознавчі тексти, 3 яких студенти черпатимуть інформацію про географічні, політичні, економічні дані; газетні статті, що висвітлюють головні перипетії та події сучасності. Усі вищезазначені складники $\epsilon$ мотивуючими чинниками на шляху оволодіння іноземною мовою та необхідними ланками у процесі формування крос-культурної компетентності.

Поняття «компетентність» $\mathrm{i}$ «компетенція» поширені в сучасній психологічній, педагогічній i лінгводидактичній думці та часто вживаються як синоніми, проте різні автори інтерпретують їх зміст по-різному. Так, у спільній праці «Феномен особистісної компетентності у просторі наукового знання» Н. Губа та М. Кандиба зазначають, що близьким за значенням до слова компетентність є поняття «поінформованість», «обізнаність», «досвідченість», «авторитетність». Автори надають оригінальний варіант поняття competens, що в перекладі 3 латинської означає «підходящий», «відповідний», «узгоджений», а competentia, відповідно, «узгодженість частин», «сумірність», «симетрія» [1, с. 54]. Це дає підстави припустити, що поняття «компетентність» $\epsilon$ ширшим за поняття «компетенція» та залучає різні види останньої до свого змісту.

За переконанням А. Хуторського, термін «компетентність» i «компетенція» не є тотожними, оскільки в них закладено різний смисл. Так, компетенція на думку науковця - це поєднання знань, умінь, навичок, способів діяльності особистості, що уможливлюють формулювання власної позиції щодо зазначеної сфери та є важливими для виконання ефективної дії в ній; компетентність - володіння 
людиною певною компетенцією, що відображає iї суб'єктивне ставлення до предмета діяльності [10].

С. Бондар зазначає, що компетентність є здатністю особистості діяти, проте жодна людина не починає активної діяльності без особистої зацікавленості. За своєю природою компетентність проявляється лише в гармонійному поєднанні 3 ціннісно-нормативною системою суб'єкта, отже основою будь-яких компетенцій є цінності $[3$, c. 205].

А. Маркова розглядає компетентність як сукупність психічних якостей i станів, що активізують самостійну діяльність та відповідальність; окреслене поняття характеризує набуття суб'єктом навичок і вмінь виконання трудових функцій. Науковець наголошує на тому, що термін «компетентність» у значенні належності до певної особи $є$ вужчим за поняття «професіоналізм». На думку дослідниці, останній властивий людині в конкретній галузі, проте вона може бути некомпетентною в розв'язанні професійних завдань [5].

Отже, аналіз понять «компетенція» і «компетентність» дає змогу зробити висновки про їх суміжність. Компетенція - сукупність взаємопов'язаних між собою знань, умінь i навичок, якостей особистості, необхідних для реалізації продуктивної діяльності, тоді як компетентність - уміння застосовувати знання, уміння і навички у певних ситуаціях та активізувати накопичений життєвий досвід під час вирішення визначеного кола питань.

3 поширенням ідей культурологічно орієнтованої освіти, для іноземних громадян, що приїжджають в Україну на навчання, максимально необхідним стає набуття міжкультурної (кроскультурної) компетентності.

Наведений термін увійшов у науковий обіг на початку 70-х років XX ст., коли особливої актуальності набули питання, пов'язані зі ставленням до представників іншої культури, подоланням монокультуралізму. У межах окреслених проблем науковці визначають крос-культурну компетентність як сукупність аналітичних i стратегічних здібностей, що збільшують інтерпретаційне поле суб' єкта під час міжкультурного спілкування [9].

Проблему визначення крос-культурної компетентності було розглянуто в дослідженнях і публікаціях Г. Антипової, Ж. Войнової, О. Дем'яненко, Т. Колосовської, О. Лапшина, Г. Ферапонтова та ін.; 
особливостям формування міжкультурної компетенції присвячені праці Н. Алмазової, Р. Гришкової, Г. Копил, І. Плужник, В. Сафонової та ін.

Так, Г. Ферапонтов уважає, що оволодіння другою мовою поряд iз отриманням фонетичних, лексичних і граматичних знань, умінь i навичок повинно також передбачати засвоєння культурологічної інформації, що в результаті являє собою набуття крос-культурної компетентності. Під останньою науковець розуміє «здатність суб'єкта культурного розвитку орієнтуватися в самоцінних культурах різних етносів» $[9$, с. 56].

Т. Колосовська визначає крос-культурну компетентність як інтегральну якість особистості, до складу якої входять знання про особливості іншої культури, уміння інтерпретувати іншокультурну інформацію, досвід комунікативної діяльності [2].

На думку О. Лапшина, крос-культурна компетентність - це усвідомлення ідейних, обрядових, культових і традиційних відмінностей, що властиві тій чи тій культурі, здатність визначити спільні та відмінні риси в різних культурах і поглянути на традиції власного народу очима іншого етносу [4].

Виходячи 3 такого розуміння міжкультурної компетентності, О. Садохін пропонує поділити іiі зміст на три категорії знань: афективні, когнітивні і процесуальні. До першої групи належать емпатія і толерантність, що створюють психологічне підгрунтя для продуктивної міжкультурної співпраці. До складу другої входять етноцентризм та етнокультурний релятивізм, що $\epsilon$ важливою умовою адекватної інтерпретації іншомовної поведінки для запобігання міжкультурних бар'єрів та зміни власної поведінки під час спілкування. Процесуальні складники крос-культурної компетентності являють собою стратегії, що використовуються під час міжкультурної взаємодії та спрямовані на іiі ефективне установлення, спонукання до мовленнєвої дії, пошук спільних культурних компонентів, розуміння та розпізнавання непорозумінь, упровадження досвіду попередніх контактів. Вони також спрямовані на збагачення суб'єкта відомостями про культурну своєрідність співрозмовника [8].

Яскравим прикладом процесуальних елементів слугує вживання в українській мові двох форм звертання: $B u$ - ввічливої та більш формальної, сферою застосування якої $\epsilon$ переважно ділове спілкування і $m u$, що вживається під час неформального спілкування 3 родичами, друзями, знайомими, дітьми. 
У своїй праці «Компетенция или компетентность: Взгляд методиста на актуальную проблему лингводидактики» О. Щукін акцентує увагу на терміні комунікативна компетентність, що $\epsilon$ показником високого рівня володіння практичними знаннями та невід'ємною частиною крос-культурної компетентності. Науковець пропонує залучити до структури міжкультурної комунікативної компетентності такі поняття як лінгвістична, мовленнєва, предметна, дискурсивна, соціокультурна та соціальна компетенції [11].

На переконання дослідника, лінгвістична компетенція являє собою сукупність знань про мовні одиниці та уміння ними послуговуватись для вираження власних думок та розуміння інформації, що надходить від мовця.

Мовленнєва компетенція позначає наявність умінь виражати думки через залучення мовних засобів, що уможливлює планування та здійснення мовленнєвого акту. Це сприяє кращому розумінню інформації й спонукає до висловлювання власних думок в усній i писемній формі під час здійснення комунікативного акту.

До змісту сочіокультурної компетенщії входять знання національно-культурної семантики країни, мова якої вивчається; мовленнєвої та немовленнєвої поведінки у визначених ситуаціях спілкування; правил етикету представників іноземного суспільства та вміння реалізувати вербальну поведінку згідно з ними.

Соціальна компетенція спонукає до комунікації 3 іншими індивідами; передбачає адаптування мовця до ситуації спілкування та моделювання висловлювання згідно 3 наміром комуніканта й можливостями партнера. Окреслений вид компетенції має також іншу назву - прагматична, якщо акцент ставиться на уміння суб'єкта обирати спосіб вираження думки, що найбільш відповідає умовам та цілям спілкування.

Дискурсивна компетенція визначає знання, необхідні для побудови дискурсу; уміння моделювання усного або письмового повідомлення 3 окремих речень та розуміння інформації, наданої іноземною мовою.

Предметна компетенція - знання матеріалу з теми спілкування, що дозволяє визначати напрям спілкування у певній сфері діяльності [11].

На думку різних дослідників під час формування кроскультурної компетентності особистість долає кілька стадій міжкультурної взаємодії.

() О. О. Пальчикова, 2012. 
Так, В. Нароліна пропонує розглянути модель формування міжкультурної комунікативної компетентності для вишів нефілологічного профілю, до складу якої входять 2 щаблі «інкультурація» та «акультурація» [6]. За визначенням О. Садохіна, інкультурація - освоєння індивідом світорозуміння та поведінки, притаманних лише визначеній культурі, у результаті чого суб'єкт набуває когнітивної, емоційної та поведінкової схожості 3 іiі представниками та відмінностей від репрезентантів інших культур; акультурація - процес і результат взаємовпливу різних культур, під час якого частина або всі представники однієї культури переймають норми, цінності та традиції іншої [7].

Підгрунтям технологічного складника моделі формування міжкультурної комунікативної компетентності В. Нароліної $\epsilon$ проблемно-діалогічний метод, що передбачає залучення трьох рівнів проблемності. Першим двом відповідають ступені «інкультурації», останньому - процес «акультурації».

На першому етапі студенти ознайомлюються 3 текстовим матеріалом, прослуховують аудіозаписи та переглядають відеосюжети 3 обраної тематики, після чого їм пропонують проаналізувати та зіставити схожі й відмінні факти про культурні, мовні, поведінкові універсалії та визначити коло питань, необхідне для обговорення 3 уявними «представниками інших культур» під час навчального діалогічного спілкування (друга стадія). На третьому етапі формування крос-культурної комунікативної компетентності студенти виходять за межі пропонованого матеріалу та самостійно вивчають нову інформацію, формулюють нові проблеми, шукають шляхи їх розв'язання у процесі крос-культурного спілкування [6].

Проаналізувавши джерела наукової літератури 3 окресленої проблеми, можна зробити висновки про те, що:

1) поняття крос-культурна компетентність позначає застосування набутих знань, умінь і навичок сприйняття, розуміння та відтворення особливостей іншомовної культури на практиці під час крос-культурних контактів;

2) до змісту крос-культурної компетентності входять лінгвістичний, культурний та психологічний компоненти, що знаходять своє відображення у таких видах компетенцій, як лінгвістична, мовленнєва, соціокультурна, соціальна, дискурсивна та предметна; 
3) формування міжкультурної компетентності проходить кілька етапів: оцінний, зіставний та дослідницький, під час яких суб'єкт ознайомлюється з іноземною культурою, зіставляє зразки поведінки й особливості світосприйняття іноземної культури 3 власною та намагається застосувати набуті знання на практиці.

\section{Література}

1. Губа Н. О. Феномен особистісної компетентності у просторі наукового знання / Н. О. Губа, М. О. Кандиба // Психологічні перспективи. - Луцьк, 2010. - Вип. 15. C. 52-61.

2. Колосовская Т. А. Формирование кросс-культурной компетентности будущих учителей : дис. ... канд. пед. Наук : 13.00.08 / Т. А. Колосовская. - Челябинск, 2006. - 195 с.

3. Кроки до компетентності та інтеграції в суспільство: наук.-метод. зб. / [ред. кол. : Н. 3. Софій, І. Г. Срмаков та ін.]. - К. : Кон-текст, 2000. - 336 с.

4. Лапшин О. Г. Международное сотрудничество в области гуманитарного образования : перспектива кросс-культурной грамотности // Кросс-культурный діалог : компаративные исследования в педагогике и психологи : сб. ст. - Владимир, 1999. -47 с.

5. Маркова А. К. Психология профессионализма : [монографія] / А. К. Маркова. М. : Международный гуманитарный фонд знание, 1996. - 308 с.

6. Наролина В. И. Подготовка специалиста к межкультурной коммуникации / В. И. Наролина // Высшее образование в России. - 2009. - № 1. - С. 124-128.

7. Садохин А. П. Введение в теорию межкультурной коммуникации / А. П. Садохин. М. : Высшая школа, 2005. $-310 \mathrm{c}$.

8. Садохин А. П. Межкультурная компетенция и компетентность в современной коммуникации / А. П. Садохин // Общественные науки и современность. - 2008. № 3. - C. 156-166.

9. Ферапонтов Г. А. Понятийный аппарат социо-кросс-культурного гражданського воспитания // Кросс-культурный поход в науке и образовании : материалы ежегодного семинара. - Вып. 5. - Новосибирск : НГПУ, 2010. - С. 56-58.

10. Хуторской А. В. Практикум по дидактике и современным методикам обучения / А. В. Хуторской. - М. : СПб и др. Питер, 2004. - 544 с.

11. Щукин А. Н. Компетенция или компетентность : Взгляд методиста на актуальную проблему лингводидактики / А.Н. Щукин // Рус. яз. за рубежом. - 2000. № 5. - C. 14-20. 